\title{
Survival of Patients Treated with Antibiotics and Immunotherapy for Cancer: A Systematic Review and Meta-Analysis
}

\author{
Fausto Petrelli ${ }^{1, *(\mathbb{D}, \text { Alessandro Iaculli }}{ }^{2}$, Diego Signorelli ${ }^{3}$, Antonio Ghidini ${ }^{4}{ }^{\circ}$, \\ Lorenzo Dottorini ${ }^{2}$, Gianluca Perego ${ }^{5}{ }^{\circ}$, Michele Ghidini ${ }^{6}$, Alberto Zaniboni ${ }^{7}$, Stefania Gori ${ }^{8}$ \\ and Alessandro Inno ${ }^{8}$ D \\ 1 Oncology Unit, ASST Bergamo Ovest, 24047 Treviglio, Italy \\ 2 Oncology Unit, ASST Bergamo Est, 24068 Alzano Lombardo, Italy; aleiaculli@gmail.com (A.I.); \\ ldottorini@gmail.com (L.D.) \\ 3 Oncology Unit, Fondazione IRCCS Istituto Nazionale Tumori di Milano, 20133 Milano, Italy; \\ diegosignorelli@yahoo.it \\ 4 Oncology Unit, Casa di cura Igea, 20129 Milano, Italy; antonioghidini@hotmail.com \\ 5 Pharmacy Unit, IRCCS San Raffaele Hospital, 20132 Milano, Italy; gianperec@gmail.com \\ 6 Oncology Unit, Fondazione IRCCS Ca' Granda Ospedale Maggiore Policlinico, 20122 Milano, Italy; \\ Michele.ghidini@policlinico.mi.it \\ 7 Oncology Unit, Fondazione Poliambulanza, 25124 Brescia, Italy; azaniboni@alice.it \\ 8 Oncology Unit, IRCCS Ospedale Sacro Cuore Don Calabria, Negrar, 37024 Verona, Italy; \\ stefania.gori@sacrocuore.it (S.G.); alessandro.inno@gmail.com (A.I.) \\ * Correspondence: faupe@libero.it
}

Received: 31 March 2020; Accepted: 11 May 2020; Published: 13 May 2020

\begin{abstract}
Antibiotics (ABs) are common medications used for treating infections. In cancer patients treated with immune checkpoint inhibitors (ICIs), concomitant exposure to ABs may impair the efficacy of ICIs and lead to a poorer outcome compared to AB non-users. We report here the results of a meta-analysis evaluating the effects of $\mathrm{ABs}$ on the outcome of patients with solid tumours treated with ICIs. PubMed, the Cochrane Library and Embase were searched from inception until September 2019 for observational or prospective studies reporting the prognoses of adult patients with cancer treated with ICIs and with or without ABs. Overall survival (OS) was the primary endpoint, and progression-free survival (PFS) was the secondary endpoint. The effect size was reported as hazard ratios (HRs) with a 95\% confidence interval (CI) and an $\mathrm{HR}>1$ associated with a worse outcome in ABs users compared to AB non-users. Fifteen publications were retrieved for a total of 2363 patients. In the main analysis ( $n=15$ studies reporting data), OS was reduced in patients exposed to ABs before or during treatment with ICIs ( $\mathrm{HR}=2.07,95 \% \mathrm{CI} 1.51-2.84 ; p<0.01)$. Similarly, PFS was inferior in AB users in $n=13$ studies with data available (HR $=1.53,95 \%$ CI 1.22-1.93; $p<0.01)$. In cancer patients treated with ICIs, AB use significantly reduced OS and PFS. Short duration/course of ABs may be considered in clinical situations in which they are strictly needed.
\end{abstract}

Keywords: cancer; immune checkpoint inhibitors; survival; antibiotic; meta-analysis

\section{Introduction}

Cancer immunotherapy with immune checkpoint inhibitors (ICIs) has demonstrated efficacy among several tumour types [1]. However, a non-negligible percentage of patients do not derive any benefit from ICIs, and the research for predictive factors may help to refine patients' selection and improve treatment efficacy. 
Preclinical studies on murine models have demonstrated that gut microbiota may act as a key modulator of efficacy and toxicity of ICIs [2,3]. Thus, it has been supposed that response to ICIs in humans could be affected by conditions that alter the composition of gut microbiota, including dysbiosis, due to the administration of antibiotics (ABs). In fact, retrospective studies reported worse outcomes for patients treated with ICIs that received ABs as compared with those which did not receive ABs [4-6].

The present meta-analysis evaluated the association between $\mathrm{AB}$ use and outcomes in patients with solid tumours treated with ICIs.

\section{Experimental Section}

\subsection{Search Strategy and Inclusion Criteria}

This meta-analysis was conducted following the Preferred Reporting Items for Systematic Reviews and Meta-Analyses (PRISMA) guidelines [7]. A systematic search was performed using Embase, PubMed, SCOPUS and Cochrane Library databases. The search was performed until September 2019 using the terms antibiotics AND (PD-1 or PD-L1 or "immune checkpoint inhibitors" or CTLA-4) AND survival. All identified articles were then independently assessed for inclusion and exclusion criteria by two investigators (Alessandro Inno and Fausto Petrelli).

The inclusion criteria used for articles selection were the following: (1) adult patients with solid tumours and treated with ICIs, (2) evaluation of survival (OS and/or PFS) according to intake of ABs (yes versus no), (3) a hazard ratio (HR) statistic accompanied by a $95 \%$ confidence interval (CI) from univariate or adjusted Cox multivariate analysis and (4) inclusion of adult patients. The exclusion criteria were the following: (1) phase I studies and (2) patients treated with ICIs and other (non-immunotherapy) drugs. When different papers published series involving overlapping patients or more extended follow-up, the most updated reports were included for quantitative assessment. Only studies involving human subjects and published in English were included.

\subsection{Data Extraction}

Two investigators (Alessandro Inno and Fausto Petrelli) independently extracted data (author and year of publication, number of patients, type of study, treatment received, timing of AB therapy, median follow-up and type of analysis). The quality of the included studies was determined with the Newcastle-Ottawa Scale (NOS) [8].

\subsection{Statistical Analysis}

The primary aim of this meta-analysis was the effect of $A B$ intake on outcome, reported as HR and its respective $95 \%$ CI. Overall survival was the primary endpoint, and PFS was the secondary endpoint. The HRs of any included study were pooled together to provide the overall effect size. $\mathrm{I}^{2}$ statistic was used to provide an estimation of the percentage of total variation across studies, owing to heterogeneity. Values greater than 50\% meant that substantial heterogeneity existed. A random-effect model was used in cases of high heterogeneity; otherwise, in the case of $\mathrm{I}^{2}<50 \%$, a fixed-effect model was appropriated [9]. Publication bias was assessed through the generation of funnel plots for OS and analysed for asymmetry using both the Begg and Egger test. All $p$ values were two-sided with significance set at $p<0.05$. Statistical analyses were conducted with the Review Manager computer program, Version 5.3 (Copenhagen: The Nordic Cochrane Centre, The Cochrane Collaboration, Copenhagen, Denmark 2014).

\section{Results}

Among the publications retrieved using electronic search, 15 studies were eligible for quantitative analysis, for a total of 2363 patients [4-6,10-21] (Figure 1). 

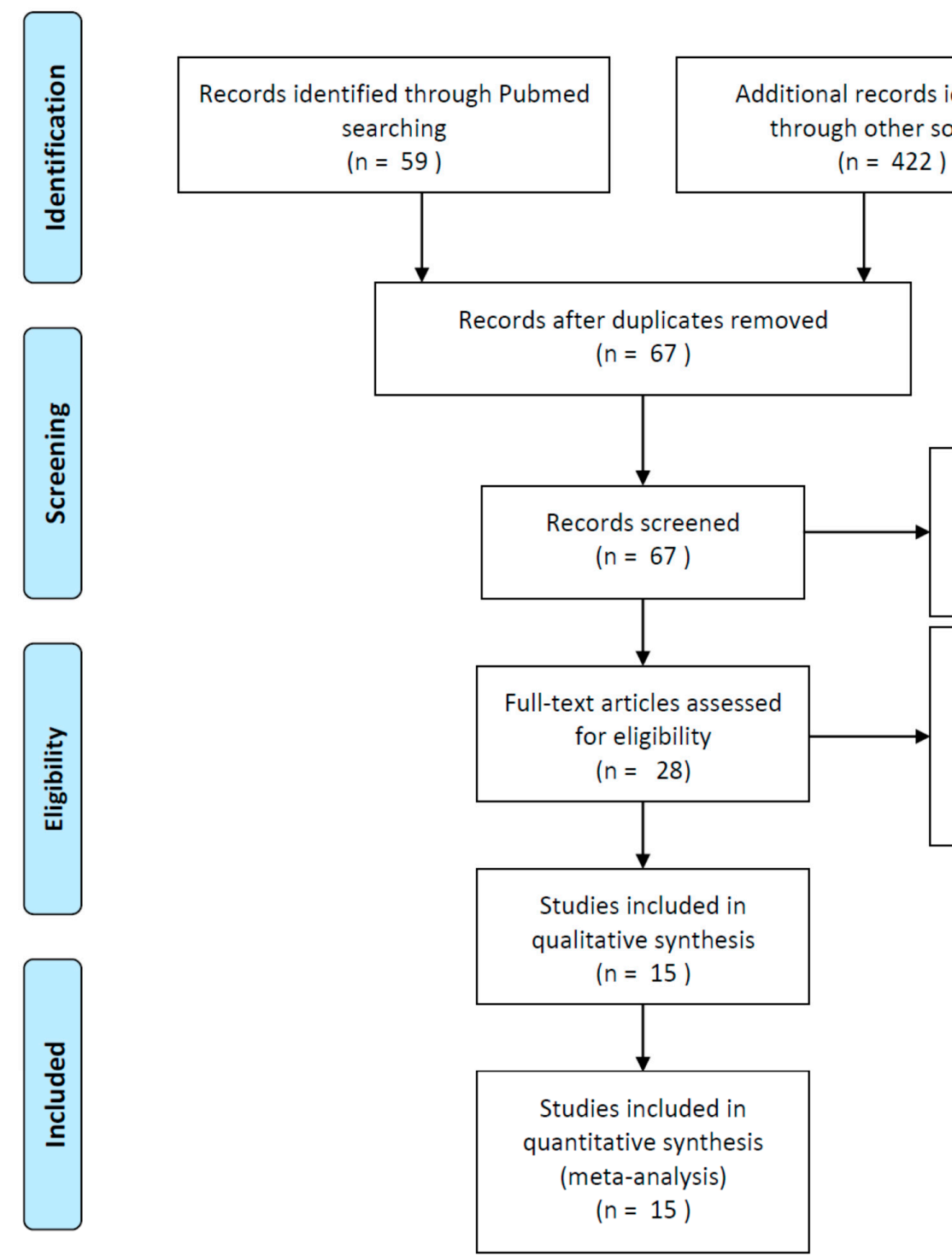

Records excluded because they did not report correlation with outcome $(n=39)$

Full-text articles excluded, because they did not reported hazard ratios, other survival data $(n=13)$

Figure 1. Flow diagram of included studies.

Baseline characteristics of the included studies and treatments received are reported in Table 1. Thirteen were retrospective series and two were prospective studies. Among the studies, 11, three and one included patients treated with ABs prior to and/or during ICIs and only prior to and only during ICIs, respectively. Median courses of ABs were rarely reported. In studies where median duration of antibiotics was reported, it was no longer than two weeks and no shorter than one week, respectively.

The median age was 64 years. Antibiotics were given to $29 \%$ of patients. Progression-free survival was reduced in those who took antibiotics ( $\mathrm{HR}=1.53,95 \%$ CI 1.22-1.93; $p<0.01$; Figure 2).

The analysis included nine studies, and due to high heterogeneity $\left(\mathrm{I}^{2}=77 \%\right)$, a random effect model was adopted.

In the primary analysis, use of antibiotics was associated with an increased risk of death ( $\mathrm{HR}=2.07$, 95\% CI 1.51-2.84; $p<0.01$; Figure 3). 
Table 1. Characteristics of included studies.

\begin{tabular}{|c|c|c|c|c|c|c|c|c|c|c|}
\hline $\begin{array}{l}\text { Author/ } \\
\text { Year }\end{array}$ & $\begin{array}{l}\text { Type of } \\
\text { Study }\end{array}$ & $\begin{array}{l}\mathrm{N}^{\circ} \\
\text { Of Patients } \\
\text { (Disease) }\end{array}$ & $\begin{array}{l}\text { Treatment } \\
\text { Received (\%) }\end{array}$ & $\begin{array}{l}\text { Median } \\
\text { Age } \\
\text { (Years) }\end{array}$ & $\begin{array}{l}\mathrm{Ab} \% \\
\text { /Timing }\end{array}$ & $\begin{array}{l}\text { Median Duration } \\
\text { (Weeks)/n }{ }^{\circ} \text { of } A B \\
\text { Courses/pts }\end{array}$ & $\begin{array}{l}\text { Med } \\
\text { FUP } \\
\text { (mos) }\end{array}$ & $\begin{array}{l}\text { Type of } \\
\text { Analysis }\end{array}$ & $\begin{array}{l}\text { Covariates } \\
\text { of MVA } \\
\text { for OS }\end{array}$ & $\begin{array}{l}\text { Quality } \\
\text { (NOS } \\
\text { Score) }\end{array}$ \\
\hline $\begin{array}{l}\text { Abu-Sbeih/ } \\
2019\end{array}$ & retrospective & $\begin{array}{l}826 \text { (melanoma } \\
n=347 ; \\
\text { hematologic } \\
n=116 ; \text { other } \\
n=363 \text { ) }\end{array}$ & $\begin{array}{l}\text { anti-PD(L)1 } \\
(51.6), \\
\text { anti-CTLA4 (32), } \\
\text { combo (16.5) }\end{array}$ & 62 & $\begin{array}{l}68.9 \\
\text { /before or after } \\
\text { start }(47.5 \%) \\
\text { both }(52.5 \%)\end{array}$ & NR/NR & NR & MVA & $\begin{array}{l}\text { ICI type, } \\
\text { Stage IV cancer, } \\
\text { IMDC, anaerobic } \\
\text { AB use }\end{array}$ & 6 \\
\hline $\begin{array}{l}\text { Ahmed/ } \\
2018\end{array}$ & retrospective & $\begin{array}{l}60 \text { (NSCLC } \\
n=34 ; \text { other } \\
n=26)\end{array}$ & $\begin{array}{l}\text { anti-PD1 (81.7), } \\
\text { anti-PDL1 (5), } \\
\text { ICI + CT (13.3) }\end{array}$ & 59 & $\begin{array}{l}28 \\
/ 2 \mathrm{w} \text { before } \\
\text { and/or after } \\
\text { start }\end{array}$ & $1-2$ & NR & MVA & $\begin{array}{l}\text { broad spectrum } \\
\text { AB use, age }\end{array}$ & 5 \\
\hline $\begin{array}{l}\text { Derosa/ } \\
2018\end{array}$ & retrospective & $\begin{array}{l}360(\mathrm{RCC} \\
n=121, \mathrm{NSCLC} \\
n=239)\end{array}$ & $\begin{array}{l}\text { RCC: anti-PD(L)1 } \\
\text { (88), anti-PD(L)1 } \\
\text { + anti-CTLA4 (8), } \\
\text { anti-PD(L)1 + } \\
\text { BEVA (4) } \\
\text { NSCLC: } \\
\text { anti-PD(L)1 (86), } \\
\text { combo (14) }\end{array}$ & 64 & $\begin{array}{l}21.5 \\
/ 1 \text { mos before } \\
\text { start }\end{array}$ & NR/NR & NR & MVA & $\begin{array}{l}\text { RCC: } a b 30-0 \\
\text { days/no AB } \\
\text { IMDC risk, } \\
\text { tumour burden } \\
\text { NSCLC: ab 30-0 } \\
\text { days/no AB, PS, } \\
\text { clinical trial } \mathrm{Y} / \mathrm{N} \text {, } \\
\text { prior regimens } \\
>/<3\end{array}$ & 5 \\
\hline $\begin{array}{l}\text { Elkrief/ } \\
2019\end{array}$ & retrospective & 59 (melanoma) * & $\begin{array}{l}\text { NIVO/PEMBRO/ } \\
\text { IPI (100) }\end{array}$ & 64.5 & $\begin{array}{l}13.5^{\circ} \\
/ 1 \text { month before }\end{array}$ & $0.9 / \mathrm{NR}$ & NR & MVA & $\begin{array}{l}\text { age, PS, gender, } \\
\text { AB use, LDH, } \\
\text { BRAF, line of } t x \text {, } \\
\text { type of ICI }\end{array}$ & 5 \\
\hline $\begin{array}{l}\text { Galli/ } \\
2019\end{array}$ & retrospective & 157 (NSCLC) & $\begin{array}{l}\text { anti-PD(L)1 } \\
(95.6), \\
\text { anti-CTLA4 o } \\
\text { combo (4.4) }\end{array}$ & 66.7 & $\begin{array}{l}17.2 \\
\text { /during ICI } \\
\text { period }\end{array}$ & 1/NR & 28.6 & MVA & $\begin{array}{l}\text { high } \mathrm{AB} \\
\text { /immunotherapy } \\
\text { exposure ratio } \\
\text { through entire } \\
\text { ICI period }\end{array}$ & 8 \\
\hline $\begin{array}{l}\text { Guo/ } \\
2019\end{array}$ & retrospective & $\begin{array}{l}49 \\
\text { (oesophageal) }\end{array}$ & $\begin{array}{l}\text { anti-PD(L1) alone } \\
(61), \text { combo (39) }\end{array}$ & 56.7 & $\begin{array}{l}43 / 2 \text { mos before } \\
\text { or } 1 \text { month } \\
\text { after }\end{array}$ & $1.42 / \mathrm{NR}$ & 16.4 & MVA & $\begin{array}{l}\text { PS, treatment, } \mathrm{n}^{\circ} \\
\text { of metastatic } \\
\text { sites, NLR, } \\
\text { antibiotic use }\end{array}$ & 7 \\
\hline
\end{tabular}


Table 1. Cont.

\begin{tabular}{|c|c|c|c|c|c|c|c|c|c|c|}
\hline $\begin{array}{l}\text { Author/ } \\
\text { Year }\end{array}$ & $\begin{array}{l}\text { Type of } \\
\text { Study }\end{array}$ & $\begin{array}{l}\mathrm{N}^{\circ} \\
\text { Of Patients } \\
\text { (Disease) }\end{array}$ & $\begin{array}{l}\text { Treatment } \\
\text { Received (\%) }\end{array}$ & $\begin{array}{l}\text { Median } \\
\text { Age } \\
\text { (Years) }\end{array}$ & $\begin{array}{l}\text { Ab\% } \\
\text { /Timing }\end{array}$ & $\begin{array}{l}\text { Median Duration } \\
\text { (Weeks)/n }{ }^{\circ} \text { of AB } \\
\text { Courses/pts }\end{array}$ & $\begin{array}{l}\text { Med } \\
\text { FUP } \\
\text { (mos) }\end{array}$ & $\begin{array}{l}\text { Type of } \\
\text { Analysis }\end{array}$ & $\begin{array}{l}\text { Covariates } \\
\text { of MVA } \\
\text { for OS }\end{array}$ & $\begin{array}{l}\text { Quality } \\
\text { (NOS } \\
\text { Score) }\end{array}$ \\
\hline $\begin{array}{l}\text { Hakozaki/ } \\
2019\end{array}$ & retrospective & 90 (NSCLC) & NIVO (100) & 68 & $\begin{array}{l}\text { 14.4/1 month } \\
\text { before start }\end{array}$ & $>1(84.6 \%) /$ & NR & MVA & driver mutations & 6 \\
\hline $\begin{array}{l}\text { Huemer/ } \\
2018\end{array}$ & retrospective & 30 (NSCLC) & $\begin{array}{l}\text { NIVO (83), } \\
\text { PEMBRO (17) }\end{array}$ & NR & $\begin{array}{l}\text { 37/1 month } \\
\text { before/after } \\
\text { start }\end{array}$ & NR/NR & NR & MVA & $\begin{array}{l}\text { sex, antibiotic } \\
\text { use, ICI, } \\
\text { EGFR/ALK } \\
\text { mutations, line of } \\
\text { tx, PDL1 status, } \\
\text { immune-related } \\
\text { adverse events }\end{array}$ & 5 \\
\hline $\begin{array}{l}\text { Huemer/ } \\
2019\end{array}$ & retrospective & 142 (NSCLC) & $\begin{array}{l}\text { NIVO, PEMBRO } \\
\text { or ATEZO (100) }\end{array}$ & 66 & $\begin{array}{l}44 / 1 \text { months } \\
\text { before or after } \\
\text { start }\end{array}$ & NR/NR & 13.3 & UVA & NR & 7 \\
\hline $\begin{array}{l}\text { Kaderbhai/ } \\
2017\end{array}$ & retrospective & 74 (NSCLC) & NIVO (100) & 67.5 & $\begin{array}{l}\text { 20.3/3 months } \\
\text { before or } \\
\text { concurrent }\end{array}$ & $1 / \mathrm{NR}$ & NR & $\begin{array}{l}\text { UVA } \\
\text { (PFS) }\end{array}$ & NR & 5 \\
\hline $\begin{array}{l}\text { Krief/ } \\
2019\end{array}$ & $\begin{array}{l}\text { prospective } \\
\text { cohort }\end{array}$ & 72 (NSCLC) & NIVO (100) & 68.8 & $\begin{array}{l}42 / 2 \text { months } \\
\text { before or } 1 \\
\text { month after } \\
\text { start }\end{array}$ & $1.35 / 1.7$ & 16.6 & MVA & $\begin{array}{l}\text { AB use; KRAS } \\
\text { mutations, } \\
\text { gemmatimonadaceae } \\
\text { on blood } \\
\text { microbiome at } \\
\text { baseline }\end{array}$ & 7 \\
\hline $\begin{array}{l}\text { Pinato/ } \\
2019\end{array}$ & $\begin{array}{l}\text { prospective } \\
\text { cohort }\end{array}$ & $\begin{array}{l}196 \text { (NSCLC } \\
n=118 ; \\
\text { melanoma } \\
n=38 ; \text { RCC } \\
n=11 ; \text { other } \\
n=26)\end{array}$ & anti-PD(L)1 (96) & 68 & $\begin{array}{l}29 / 1 \text { month } \\
\text { before or } \\
\text { concurrent }\end{array}$ & NR/NR & NR & MVA & $\begin{array}{l}\text { response to ICI, } \\
\text { AB 0-30 days } \\
\text { before ICI }\end{array}$ & 6 \\
\hline
\end{tabular}


Table 1. Cont.

\begin{tabular}{|c|c|c|c|c|c|c|c|c|c|c|}
\hline $\begin{array}{l}\text { Author/ } \\
\text { Year }\end{array}$ & $\begin{array}{l}\text { Type of } \\
\text { Study }\end{array}$ & $\begin{array}{l}\mathrm{N}^{\circ} \\
\text { Of Patients } \\
\text { (Disease) }\end{array}$ & $\begin{array}{l}\text { Treatment } \\
\text { Received (\%) }\end{array}$ & $\begin{array}{l}\text { Median } \\
\text { Age } \\
\text { (Years) }\end{array}$ & $\begin{array}{l}\mathbf{A b} \% \\
/ \text { Timing }\end{array}$ & $\begin{array}{l}\text { Median Duration } \\
\text { (Weeks)/n of AB } \\
\text { Courses/pts }\end{array}$ & $\begin{array}{l}\text { Med } \\
\text { FUP } \\
\text { (mos) }\end{array}$ & $\begin{array}{l}\text { Type of } \\
\text { Analysis }\end{array}$ & $\begin{array}{l}\text { Covariates } \\
\text { of MVA } \\
\text { for OS }\end{array}$ & $\begin{array}{l}\text { Quality } \\
\text { (NOS } \\
\text { Score) }\end{array}$ \\
\hline $\begin{array}{l}\text { Sen/ } \\
2018\end{array}$ & retrospective & $\begin{array}{l}172 \text { (NSCLC } \\
n=21 ; \text { RCC } \\
n=25 ; \\
\text { melanoma } \\
n=16 ; \text { sarcoma } \\
n=16 ; \text { other } \\
n=94)\end{array}$ & $\begin{array}{l}\text { anti-CTLA4 (61), } \\
\text { anti-PD1 (39) }\end{array}$ & 60 & $\begin{array}{l}\text { 33/during and } \\
\text { up to } 2 \text { mos } \\
\text { before }\end{array}$ & NR/NR & NR & UVA & NR & 5 \\
\hline $\begin{array}{l}\text { Tinsley/ } \\
2019\end{array}$ & retrospective & $\begin{array}{l}291 \text { (melanoma } \\
n=179, \text { RCC } \\
n=48, \text { NSCLC } \\
n=69 \text { ) }\end{array}$ & NR & 66 & $\begin{array}{l}32 / 2 w \text { before } \\
\text { up to } 6 w \text { after } \\
\text { start }\end{array}$ & NR/NR & NR & MVA & $\begin{array}{l}\text { AB use, } \\
\text { comorbidities, } \\
\text { metastatic sites } \\
>3, \text { PS }>0\end{array}$ & 6 \\
\hline $\begin{array}{l}\text { Zhao/ } \\
2019\end{array}$ & retrospective & 109 (NSCLC) & $\begin{array}{l}\text { anti-PD1 (52.3), } \\
\text { anti-PD1 + CT } \\
(30.3), \text { anti-PD1 + } \\
\text { antiangiogenic } \\
(17.4)\end{array}$ & 62 & $\begin{array}{l}18.3 / 1 \text { mos } \\
\text { before or after } \\
\text { start }\end{array}$ & NR/NR & NR & MVA & $\mathrm{AB}$ use, $\mathrm{PS}$ & 6 \\
\hline
\end{tabular}

* only immunotherapy without chemotherapy; ${ }^{\circ}$ : all patients; AB: antibiotic; mos: months; RCC: renal cell carcinoma; NSCLC: non-small-cell lung cancer; PD1: programmed death 1; PDL1: programmed death-ligand 1; ICI: immune checkpoint inhibitors; CT: chemotherapy; CTLA4: Cytotoxic T-lymphocyte antigen 4; BEVA: bevacizumab; NIVO: nivolumab; PEMBRO: pembrolizumab; IPI: ipilimumab; ATEZO: atezolizumab; MVA: multivariate analysis; UVA: univariate analysis; PFS: progression-free survival; IMDC: international metastatic RCC database consortium; PS ECOG: performance status; tx: therapy; NLR: neutrophil to lymphocyte ratio; NR: not reported; AB: antibiotics; combo: combination of two immune checkpoint inhibitors. 


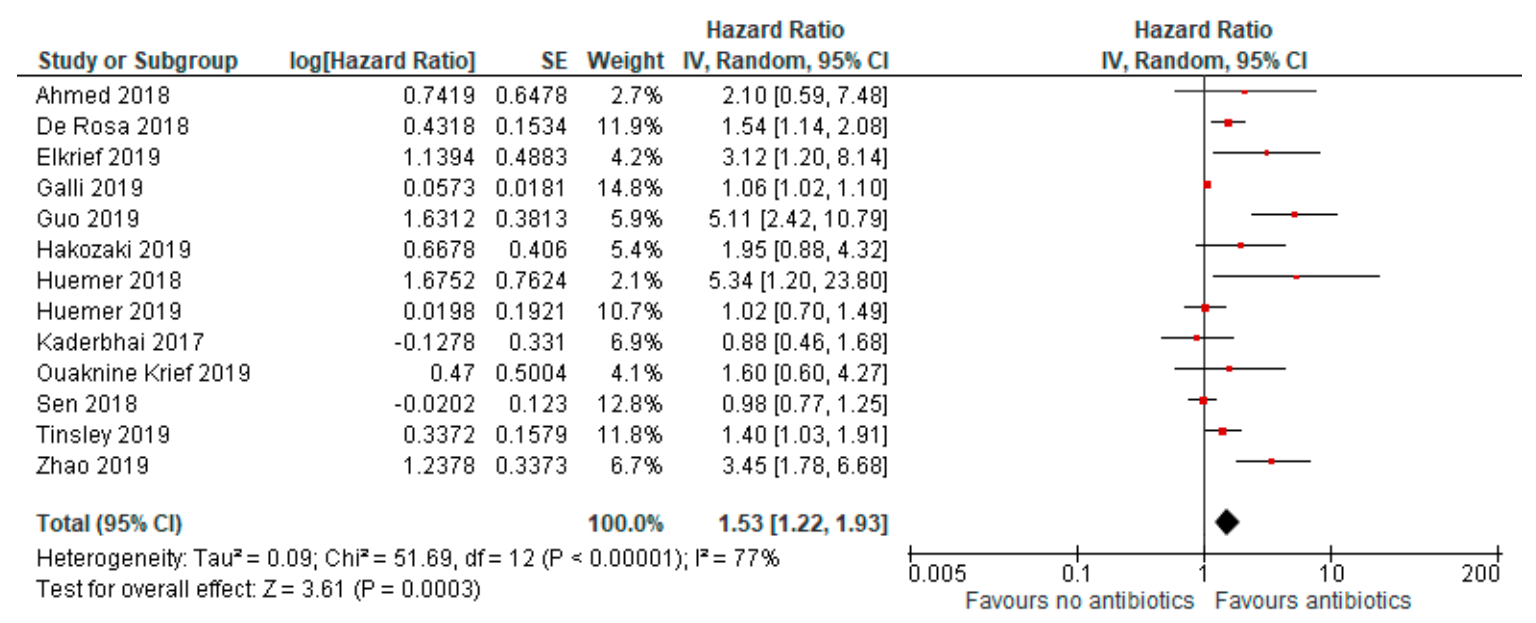

Figure 2. Forrest plot for progression-free survival in patients assuming antibiotics pre/during immunotherapy. IV, inverse variance; CI, confidence interval; SE, standard error.

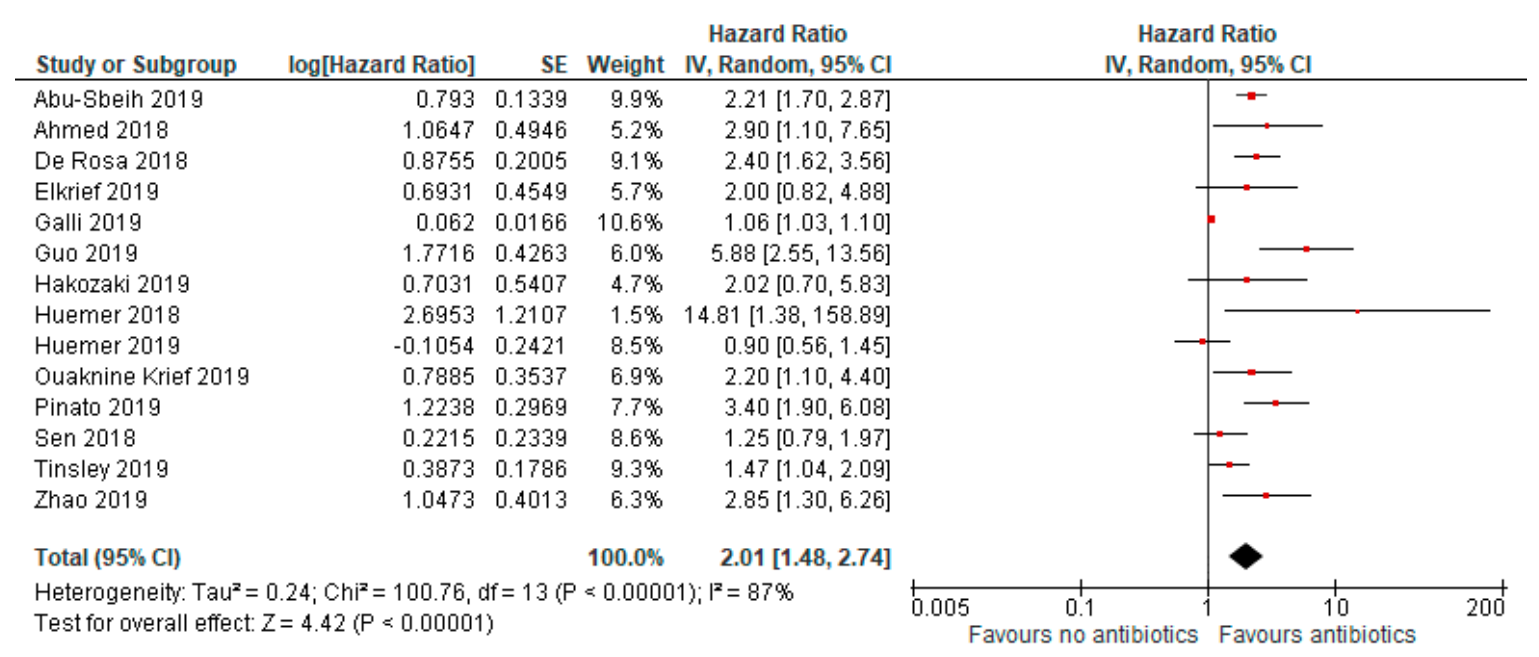

Figure 3. Forrest plot for overall survival in patients assuming antibiotics pre/during immunotherapy.

The analysis included 14 studies, and due to high heterogeneity $\left(\mathrm{I}^{2}=87 \%\right)$, a random effect model was adopted.

Risk of bias through Begg's funnel plot was not significant for the OS and PFS analysis (Figures 4 and 5). Conversely, Egger's test showed evidence of bias ( $p<0.01$ for both analysis). After adjusting for missing studies through the trim and fill method, we found that the point estimate of the overall effect size remained significant only for OS analysis $\mathrm{HR}=1.65(95 \% \mathrm{CI}, 1.25-2.17)$. After the one study removal procedure, we showed that after removing one study at a time the HRs ranged from 1.86 to 2.17, with the Guo et al. paper exerting the largest effect on OS.

Subgroup analysis was performed on the timing of antibiotics. Only one study included patients treated with ABs exclusively during ICIs (Galli et al.), and it did not report any reduced survival. Two other authors presented results of the effect of prior AB use with respect to start of ICIs (Derosa et al. and Elkrief et al.), and aggregated analysis of these two papers showed a similar effect size (HR $=2.33$, $95 \%$ CI $1.33-3.34 ; p<0.01$ ). All other publications included a mixed group of patients given ABs before and/or during ICIs (survival data not split for timing), so a formal analysis of these studies was not presented but results were similar to main analysis ( $\mathrm{HR}=2.11,95 \% \mathrm{CI} 1.54-2.9 ; p<0.01)$. Similarly, analysing the effect of administering $\mathrm{AB}$ classes or courses of $\mathrm{ABs}$ was not possible due to a lack of data. After excluding studies where analysis was not adjusted (univariate analysis), the effect on OS of $\mathrm{AB}$ use was more robust $(\mathrm{HR}=2.33,95 \% \mathrm{CI} 1.61-2.37 ; p<0.01)$. 
A meta-regression analysis was performed adjusting for median ABs duration, median follow up, disease sites and number of study patients (the only covariates with adequate number of data for analysis). No significant correlation was found to explain heterogeneity.

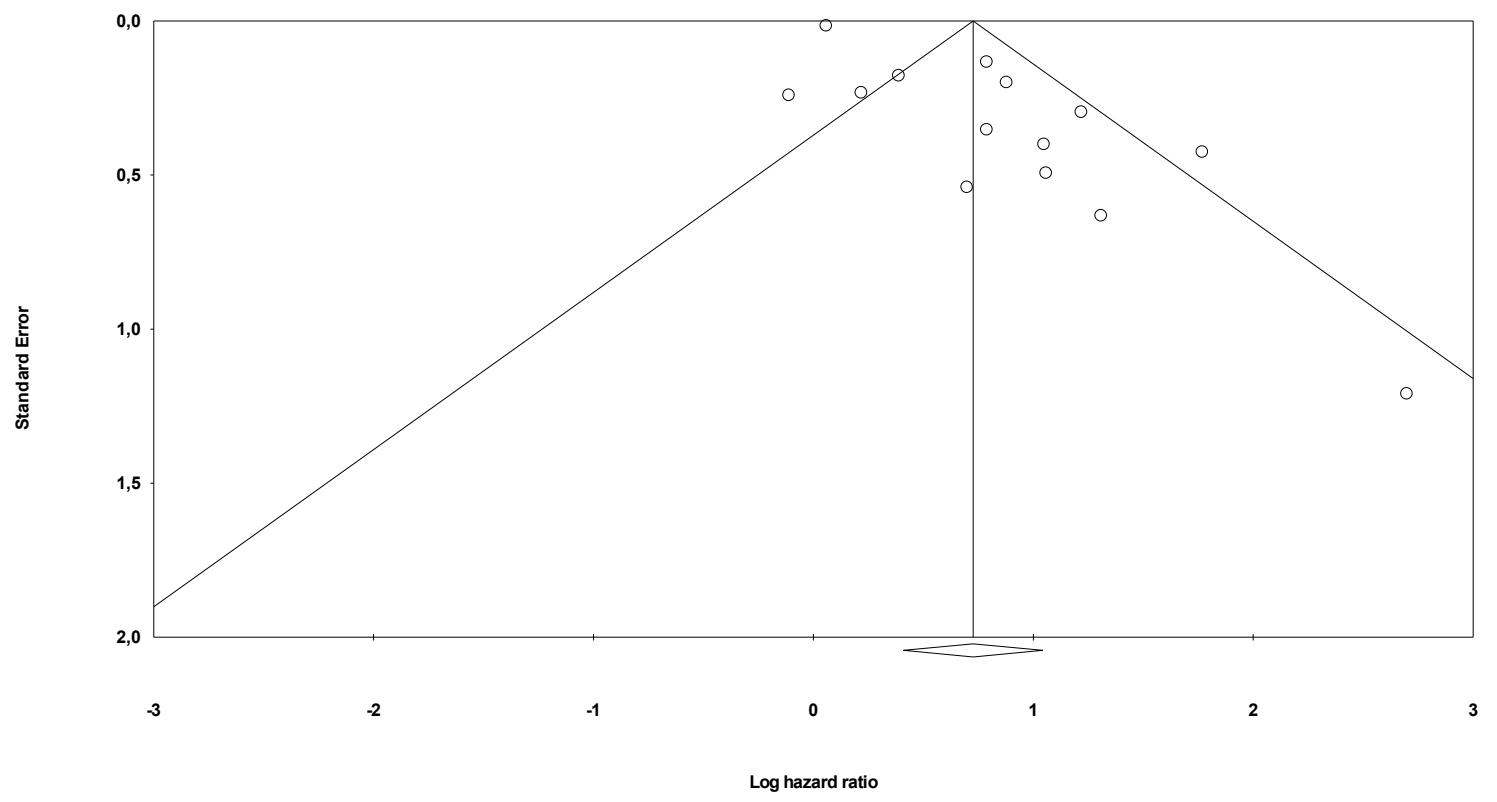

Figure 4. Funnel plot for publication bias (OS).

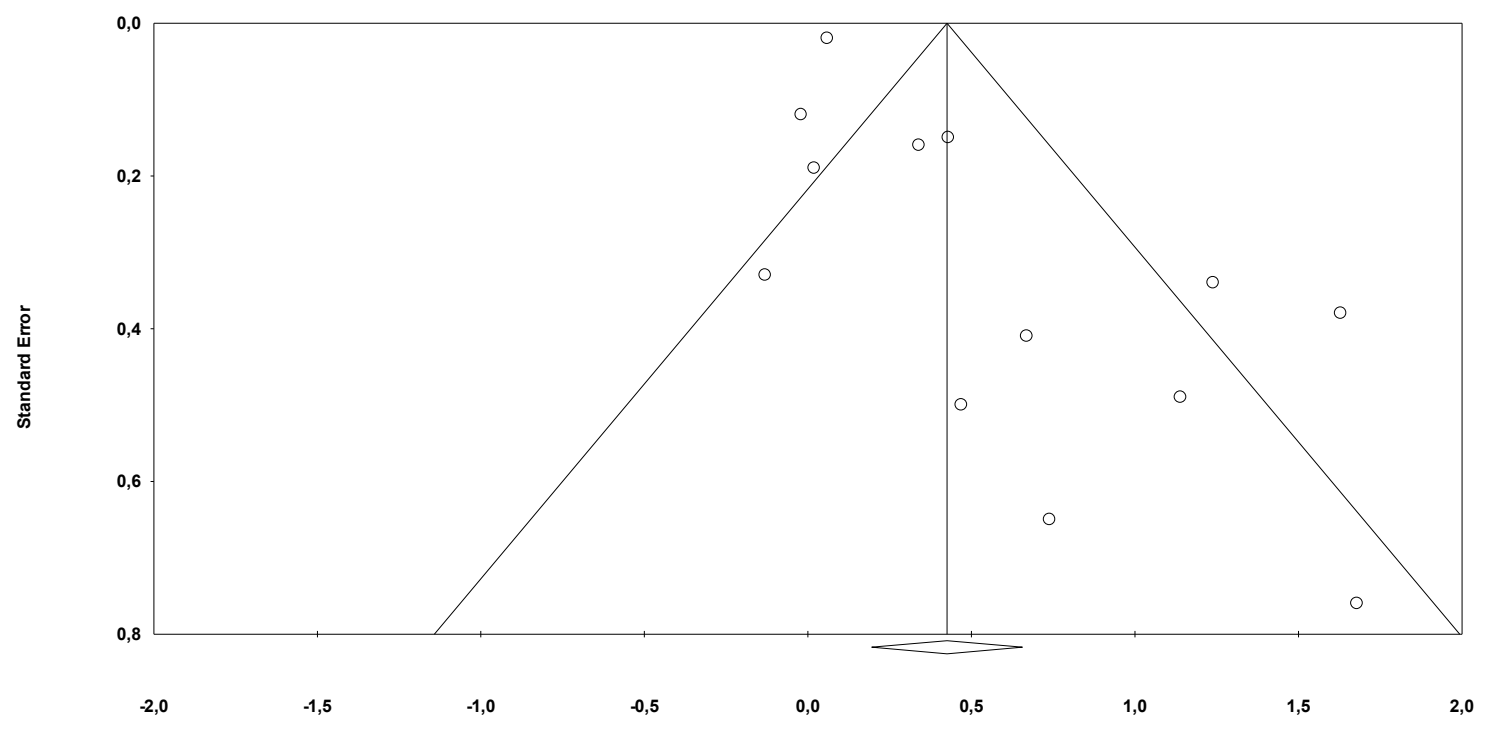

Figure 5. Funnel plot for publication bias (PFS).

\section{Discussion}

In the past years, it has been reported that changes in the gut microbiota of individuals with cancer who received antibiotics may reduce the outcome when they are treated with ICIs. We performed a systematic review and meta-analysis of observational evidence reporting the outcome of patients treated with ICIs for advanced cancers according to $\mathrm{AB}$ exposure, and we found that use of $\mathrm{ABs}$ reduces OS and PFS.

In a seminal paper published in Science in 2018, Routy et al. [22] showed that AB consumption is associated with reduced response to the anti-PD-(L)1 blockade. Samples attained from patients with lung and kidney cancer showed that non-responding patients had low levels of the bacterium Akkermansia muciniphila. Oral bacterium supplementation in antibiotic-treated mice restored the response to immunotherapy. Gopalakrishnan et al. and Matson et al. $[23,24]$ evaluated faecal 
samples from melanoma patients receiving anti-PD-(L)1 blockade and found that those who failed immunotherapy had an imbalance in commensal bacteria composition which was linked with impaired activity of immune cells. Other authors found that faecal Bifidobacterium was associated with the antitumor effects of ICIs3. Oral administration of Bifidobacterium alone also improved tumour control to the same magnitude as anti-PD-(L)1 therapy, and combination treatment nearly abolished tumour outgrowth. Increased dendritic cell function with a consensual enhanced cluster of differentiation 8 $(C D 8)+T$ cell priming/accumulation in the tumour microenvironment mediated the observed effect. Similarly, even the antitumor effect of Cytotoxic T-Lymphocyte Antigen 4 (CTLA-4) blockade seems to depend on distinct Bacteroides species, as found in mouse models by Vétizou et al. [25]. Lack of response was overcome by $B$. fragilis by immunization with $B$. fragilis polysaccharides or by adoptive transfer of $B$. fragilis-specific T cells; conversely, AB-treated mice did not respond to CTLA-4 blockade.

In clinical settings, several authors reported a possible detrimental association between timing of/exposure to ABs and survival with ICIs. Particularly, Galli et al. [5] found that an elevated ratio between days of antibiotics and days of immunotherapy is more harmful than the use of ABs itself. In a similar study, Tinsley et al. [26] observed that a single course of ABs is associated with a better OS than that of multiple/prolonged courses of ABs. Although these observations are consistent with a possible detrimental effect of $A B s$, it cannot be excluded that $A B$ use may identify a group of patients with poor prognoses due to concomitant severe infections or comorbidities, rather than ABs themselves affecting the outcome of patients treated with ICIs.

Our meta-analysis has some limitations. First, this is a meta-analysis of retrospective series with heterogeneous populations and obvious diversity in tumour stages/types and patient characteristics. $\mathrm{AB}$ type and duration, as well as the indication of $\mathrm{AB}$ use, were only partially reported. Third, there is a potential bias linked to covariates used in con multivariate analysis, sample sizes, follow-up and clinical characteristic of populations included. Fourth, a direct association between AB use and the effect on microbiota and then on OS cannot be concluded because no concomitant evaluation of gut microbiota composition under antimicrobial influence was addressed. Finally, patients treated with anticancer therapy other than ICIs were not included. However, this pooled analysis of real-life experiences seems to confirm the hypothesis that $\mathrm{AB}$-associated dysbiosis might be detrimental in patients treated with ICIs. A recently published paper by Huang and colleagues had the same goal of the present meta-analysis but with a less updated literature search, and about half of the included papers were congress abstract forms but they came to a similar conclusion [27].

\section{Conclusions}

An intact gut microbiota is needed to elicit the immune system and provide ICI benefits to cancer patients. Strategies to modulate the microbiome with the aim to improve ICI efficacy should be actively investigated.

Author Contributions: Conceptualization, F.P., A.Z.; methodology, F.P., A.Z.; software, F.P.; validation. S.G.; formal analysis, F.P.; investigation, F.P.; resources, F.P., A.Z.; data curation, F.P., M.G.; writing-original draft preparation, F.P., A.I. (Alessandro Inno); writing-review \& editing, A.I. (Alessandro Iaculli), D.S., A.G., L.D., G.P.; visualization, M.G.; supervision, A.Z., S.G.; project administration, F.P., A.I. (Alessandro Inno).; funding acquisition, A.Z. All authors have read and agreed to the published version of the manuscript.

Funding: This research received no external funding.

Conflicts of Interest: The authors declare no conflict of interest.

\section{References}

1. Ribas, A.; Wolchok, J.D. Cancer immunotherapy using checkpoint blockade. Science 2018, 359, 1350-1355. [CrossRef] [PubMed]

2. Gori, S.; Inno, A.; Belluomini, L.; Bocus, P.; Bisoffi, Z.; Russo, A.; Arcaro, G. Gut microbiota and cancer: How gut microbiota modulates activity, efficacy and toxicity of antitumoral therapy. Crit. Rev. Oncol. 2019, 143, 139-147. [CrossRef] [PubMed] 
3. Sivan, A.; Corrales, L.; Hubert, N.; Williams, J.B.; Aquino-Michaels, K.; Earley, Z.M.; Benyamin, F.W.; Lei, Y.M.; Jabri, B.; Alegre, M.-L.; et al. Commensal Bifidobacterium promotes antitumor immunity and facilitates anti-PD-L1 efficacy. Science 2015, 350, 1084-1089. [CrossRef]

4. DeRosa, L.; Hellmann, M.; Spaziano, M.; Halpenny, D.; Fidelle, M.; Rizvi, H.; Long, N.; Plodkowski, A.; Arbour, K.; Chaft, J.; et al. Negative association of antibiotics on clinical activity of immune checkpoint inhibitors in patients with advanced renal cell and non-small-cell lung cancer. Ann. Oncol. 2018, 29, 1437-1444. [CrossRef] [PubMed]

5. Galli, G.; Triulzi, T.; Proto, C.; Signorelli, D.; Imbimbo, M.; Poggi, M.; Fucà, G.; Ganzinelli, M.; Vitali, M.; Palmieri, D.; et al. Association between antibiotic-immunotherapy exposure ratio and outcome in metastatic non small cell lung cancer. Lung Cancer 2019, 132, 72-78. [CrossRef]

6. Tinsley, N.; Zhou, C.; Tan, G.; Rack, S.; Lorigan, P.C.; Blackhall, F.; Krebs, M.; Carter, L.; Thistlethwaite, F.; Graham, D.; et al. Cumulative Antibiotic Use Significantly Decreases Efficacy of Checkpoint Inhibitors in Patients with Advanced Cancer. Oncologist 2019, 25, 55-63. [CrossRef]

7. Moher, D.; Liberati, A.; Tetzlaff, J.; Altman, D.G.; Group, P. Preferred reporting items for systematic reviews and meta-analyses: The PRISMA statement. BMJ 2009, 339, b2535. [CrossRef]

8. Wells, G.; Shea, B.; O'Connell, D. The Newcastle-Ottawa Scale (NOS) for Assessing the Quality if Nonrandomizes Studies in Meta-Analyses. Available online: http:/www.ohri.ca/programs/clinical_ epidemiology/oxford.asp (accessed on 29 December 2019).

9. Higgins, J.P.T.; Thompson, S.G.; Deeks, J.J.; Altman, U.G. Measuring inconsistency in meta-analyses. BMJ 2003, 327, 557-560. [CrossRef]

10. Abu-Sbeih, H.; Herrera, L.N.; Tang, T.; Altan, M.; Chaftari, A.-M.; Okhuysen, P.C.; Jenq, R.R.; Wang, Y. Impact of antibiotic therapy on the development and response to treatment of immune checkpoint inhibitor-mediated diarrhea and colitis. J. Immunother. Cancer 2019, 7, 242. [CrossRef]

11. Ahmed, J.; Kumar, A.; Parikh, K.; Anwar, A.; Knoll, B.M.; Puccio, C.; Chun, H.; Fanucchi, M.; Lim, S.H. Use of broad-spectrum antibiotics impacts outcome in patients treated with immune checkpoint inhibitors. OncoImmunology 2018, 7, e1507670-e1507676. [CrossRef]

12. Elkrief, A.; El Raichani, L.; Richard, C.; Messaoudene, M.; Belkaid, W.; Malo, J.; Belanger, K.; Miller, W.; Jamal, R.; Letarte, N.; et al. Antibiotics are associated with decreased progression-free survival of advanced melanoma patients treated with immune checkpoint inhibitors. OncoImmunology 2019, 8, e1568812-e1568816. [CrossRef] [PubMed]

13. Guo, J.-C.; Lin, C.-C.; Lin, C.-Y.; Hsieh, M.-S.; Kuo, H.-Y.; Lien, M.-Y.; Shao, Y.-Y.; Huang, T.-C.; Hsu, C.-H. Neutrophil-to-lymphocyte Ratio and Use of Antibiotics Associated with Prognosis in Esophageal Squamous Cell Carcinoma Patients Receiving Immune Checkpoint Inhibitors. Anticancer Res. 2019, 39, 5675-5682. [CrossRef] [PubMed]

14. Hakozaki, T.; Okuma, Y.; Omori, M.; Hosomi, Y. Impact of prior antibiotic use on the efficacy of nivolumab for non-small cell lung cancer. Oncol. Lett. 2019, 17, 2946-2952. [CrossRef] [PubMed]

15. Huemer, F.; Lang, D.; Westphal, T.; Gampenrieder, S.P.; Hutarew, G.; Weiss, L.; Hackl, H.; Lamprecht, B.; Rinnerthaler, G.; Greil, R.; et al. Baseline Absolute Lymphocyte Count and ECOG Performance Score Are Associated with Survival in Advanced Non-Small Cell Lung Cancer Undergoing PD-1/PD-L1 Blockade. J. Clin. Med. 2019, 8, 1014. [CrossRef]

16. Huemer, F.; Rinnerthaler, G.; Westphal, T.; Hackl, H.; Hutarew, G.; Gampenrieder, S.P.; Weiss, L.; Greil, R. Impact of antibiotic treatment on immune-checkpoint blockade efficacy in advanced non-squamous non-small cell lung cancer. Oncotarget 2018, 9, 16512-16520. [CrossRef]

17. Kaderbhai, C.; Richard, C.; Fumet, J.D.; Aarnink, A.; Foucher, P.; Coudert, B.; Favier, L.; Lagrange, A.; Limagne, E.; Boidot, R.; et al. Antibiotic Use Does Not Appear to Influence Response to Nivolumab. Anticancer Res. 2017, 37, 3195-3200. [CrossRef]

18. Krief, J.O.; De Tauriers, P.H.; Duménil, C.; Neveux, N.; Dumoulin, J.; Giraud, V.; Labrune, S.; Tisserand, J.; Julie, C.; Emile, J.-F.; et al. Role of antibiotic use, plasma citrulline and blood microbiome in advanced non-small cell lung cancer patients treated with nivolumab. J. Immunother. Cancer 2019, 7, 176. [CrossRef]

19. Pinato, D.J.; Howlett, S.; Ottaviani, D.; Urus, H.; Patel, A.; Mineo, T.; Brock, C.; Power, D.; Hatcher, O.; Falconer, A.; et al. Association of Prior Antibiotic Treatment with Survival and Response to Immune Checkpoint Inhibitor Therapy in Patients With Cancer. JAMA Oncol. 2019, 5, 1774. [CrossRef] 
20. Sen, S.; Pestana, R.C.; Hess, K.; Viola, G.; Subbiah, V. Impact of antibiotic use on survival in patients with advanced cancers treated on immune checkpoint inhibitor phase I clinical trials. Ann. Oncol. 2018, 29, 2396-2398. [CrossRef]

21. Zhao, S.; Gao, G.; Li, W.; Li, X.; Zhao, C.; Jiang, T.; Jia, Y.; He, Y.; Li, A.; Su, C.; et al. Antibiotics are associated with attenuated efficacy of anti-PD-1/PD-L1 therapies in Chinese patients with advanced non-small cell lung cancer. Lung Cancer 2019, 130, 10-17. [CrossRef]

22. Routy, B.; Le Chatelier, E.; DeRosa, L.; Duong, C.P.; Alou, M.T.; Daillère, R.; Fluckiger, A.; Messaoudene, M.; Rauber, C.; Roberti, M.P.; et al. Gut microbiome influences efficacy of PD-1-based immunotherapy against epithelial tumors. Science 2017, 359, 91-97. [CrossRef] [PubMed]

23. Gopalakrishnan, V.; Spencer, C.N.; Nezi, L.; Reuben, A.; Andrews, M.C.; Karpinets, T.V.; Prieto, P.A.; Vicente, D.; Hoffman, K.; Wei, S.C.; et al. Gut microbiome modulates response to anti-PD-1 immunotherapy in melanoma patients. Science 2017, 359, 97-103. [CrossRef] [PubMed]

24. Matson, V.; Fessler, J.; Bao, R.; Chongsuwat, T.; Zha, Y.; Alegre, M.-L.; Luke, J.J.; Gajewski, T.F. The commensal microbiome is associated with anti-PD-1 efficacy in metastatic melanoma patients. Science 2018, 359, 104-108. [CrossRef] [PubMed]

25. Vétizou, M.; Pitt, J.M.; Daillère, R.; Lepage, P.; Waldschmitt, N.; Flament, C.; Rusakiewicz, S.; Routy, B.; Roberti, M.P.; Duong, C.P.; et al. Anticancer immunotherapy by CTLA-4 blockade relies on the gut microbiota. Science 2015, 350, 1079-1084. [CrossRef]

26. Tinsley, N.; Zhou, C.; Villa, S.; Tan, G.; Lorigan, P.C.; Blackhall, F.H.; Elliott, T.; Krebs, M.G.; Carter, L.; Thistlethwaite, F.; et al. Cumulative antibiotic use and efficacy of immune checkpoint inhibitors in patients with advanced cancer. J. Clin. Oncol. 2018, 36, 3010. [CrossRef]

27. Huang, X.-Z.; Gao, P.; Song, Y.-X.; Xu, Y.; Sun, J.-X.; Chen, X.-W.; Zhao, J.-H.; Wang, Z.-N. Antibiotic use and the efficacy of immune checkpoint inhibitors in cancer patients: A pooled analysis of 2740 cancer patients. OncoImmunology 2019, 8, e1665973. [CrossRef] [PubMed]

(C) 2020 by the authors. Licensee MDPI, Basel, Switzerland. This article is an open access article distributed under the terms and conditions of the Creative Commons Attribution (CC BY) license (http://creativecommons.org/licenses/by/4.0/). 